\title{
Absorption and critical levels of phosphorus in castor bean shoots grown in different soil classes
}

\section{Absorção e níveis críticos de fósforo na parte aérea da mamoneira cultivada em diferentes classes de solos}

\author{
José Félix de Brito Neto ${ }^{1 *}$; Leonardo Theodoro Büll ${ }^{2}$; Napoleão Esberard de \\ Macêdo Beltrão ${ }^{3}$; João Paulo Gonsiorkiewicz Rigon ${ }^{4}$; Valdinei Sofiatti ${ }^{3}$
}

\begin{abstract}
Soil that has a high degree of weathering, with more inorganic $\mathrm{P}$ bound to $\mathrm{Fe}$ and $\mathrm{Al}$ oxides, has less $\mathrm{P}$ availability to plants. Thus, the critical element of a plant refers to the level below which the growth rate and plant production decreases, demonstrating the need for supplementary fertilization. Accordingly, an experiment was conducted in a greenhouse at Embrapa Algodão with the objective of evaluating the response of castor plants to five doses of $\mathrm{P}$ in four types of soil with different adsorption characteristics and critical levels of foliar P. The experimental design was completely randomized in a 4 x 5 factorial design, four types of soil and 5 levels of $\mathrm{P}$ with four replications. For TCo, there was an increase in height growth, with dose of $229.6 \mathrm{mg} \mathrm{dm}^{-3}$ responsible for maximum plant height $(74.3 \mathrm{~cm})$. The largest diameter stem $(17.58 \mathrm{~mm})$ was observed in CXve with an application of $229.6 \mathrm{mg} \mathrm{dm}^{-3}$ of P; a decrease was seen when using higher doses. The increase in leaf area was smaller in RY $\left(4724.8 \mathrm{~cm}^{2}\right)$, where it was obtained with a dose of $280.2 \mathrm{mg} \mathrm{dm}^{-3}$. In general, critical levels of $\mathrm{P}$ in the plant shoots did not vary much between the soils. The critical level of $P$ in castor bean shoot dry mass was higher $\left(4.61 \mathrm{~g} \mathrm{~kg}^{-1}\right)$ in TCo, this result being directly related to the low clay content of the soil.
\end{abstract}

Key words: Availability, plants, phosphorus, castor bean

\section{Resumo}

Solos que apresenta alto grau de intemperismo, com maior fração do P inorgânico ligada a óxidos de $\mathrm{Fe}$ e Al, apresentam baixa disponibilidade de P para as plantas. Assim, o nível crítico de um elemento na planta refere-se ao teor, abaixo do qual a taxa de crescimento ou a produção vegetal diminui, demonstrando a necessidade de adubação complementar. Nesse sentido, foi conduzido um experimento em casa de vegetação na Embrapa Algodão, com o objetivo de avaliar a resposta da mamoneira a cinco doses de $\mathrm{P}$ em quatro tipos de solo com diferentes características de adsorção, e estimar os níveis críticos foliares $\mathrm{P}$. O delineamento experimental utilizado foi o inteiramente casualizado, em esquema fatorial 4x5, sendo quatro tipos de solo e cinco doses de P com quatro repetições. Para o TCo, houve incremento no crescimento em altura, sendo a dose de $229,6 \mathrm{mg} \mathrm{dm}^{-3}$ responsável pela máxima altura da planta $(74,3 \mathrm{~cm})$. O maior diâmetro caulinar $(17,58 \mathrm{~mm})$ foi observado no CXve com aplicação de $229,6 \mathrm{mg} \mathrm{dm}^{-3}$ de $\mathrm{P}$, verificando-se decréscimo quando se utilizou doses superiores. O crescimento em

\footnotetext{
${ }^{1}$ Eng $^{\circ}$ Agr $^{\circ}$, Dr. Empresa Brasileira de Pesquisa Agropecuária, EMBRAPA, Centro Nacional de Pesquisa de Algodão, Centenário, Campina Grande-PB, Brasil. E-mail: jose.felix@embrapa.br

${ }^{2}$ Prof. Dr. da Faculdade de Ciências Agronômicas, FCA/UNESP, Botucatu, SP, Brasil. E-mail: bull@fca.unesp.br

${ }^{3}$ Pesquisadores Drs. da EMBRAPA, Centro Nacional de Pesquisa de Algodão, Centenário, Campina Grande, PB, Brasil. E-mail: napoleao.beltrao@embrapa.br; valdinei.sofiatti@embrapa.br

${ }^{4}$ Discente do Programa de Pós Graduação em Agricultura, Faculdade de Ciências Agronômicas, FCA/UNESP, Botucatu, SP, Brasil. E-mail: jprigon@fca.unesp.br

* Author for correspondence
} 
área foliar foi menor no RY $\left(4724,8 \mathrm{~cm}^{2}\right)$ sendo obtida com a dose de $280,2 \mathrm{mg} \mathrm{dm}^{-3}$. De forma geral os níveis críticos de $\mathrm{P}$ na parte aérea da planta não variaram muito dentre os solos estudados. $\mathrm{O}$ nível crítico de P na massa seca da parte aérea da mamoneira foi maior $\left(4,61 \mathrm{~g} \mathrm{~kg}^{-1}\right)$ no TCo, estando esse resultado diretamente relacionado com o baixo teor de argila desse solo.

Palavras-chave: Disponibilidade, plantas, fósforo, mamona

\section{Introduction}

The castor bean (Ricinus communis L.) is considered a rustic plant tolerant to water stress (BELTRÃO; AZEVEDO, 2007). Despite its hardiness, their growth and productivity may be reduced by several factors, such as low nutrient availability in the soil (COSTA et al., 2011). Among the major nutrients required by this plant, there is phosphorus, which plays multiple important roles in the plant; insufficiencies may interfere with oil content and fruit ripening (SEVERINO et al., 2006). Despite being considered one of the elements that limits the productivity of most crops, $\mathrm{P}$ is one of the macronutrients required in small quantities (GATIBONI, 2003). Some soils have a high degree of weathering, with large amounts of iron and aluminum oxides and clays of the kaolinite group of minerals that are characterized by the presence of loads (ALLEN; HAJEK, 1989). Thus, the soil may behave as a source of phosphorus when present in good quantity to supply $\mathrm{P}$ to the plants, or as a drain when $\mathrm{P}$ is adsorbed by colloids and becomes unavailable to plants.

With increased weathering, soils become more electropositive, passing the adsorbing anions more such as phosphates (NOVAIS; SMYTH, 1999). Many of these weathered soils, and some even less weathered, despite not having low total contents of $\mathrm{P}$, appear deficient in available $\mathrm{P}$ due to the low solubility of the major forms of $\mathrm{P}$ they contain and the strong interaction of the phosphate with the soil, forming compounds of low solubility due to combinations with iron, aluminum, calcium, organic matter and other elements (ROLIM NETO et al., 2004). Chemical analysis of soil is the main tool for information about their fertility, and necessary to the recommendation for phosphorus in order to supply the nutritional needs of castor beans and increase their productivity. The objective of this work was to analyze initial growth and dry matter production and determine the critical level of $\mathrm{P}$ in castor bean plants in soils with different adsorption characteristics for $\mathrm{P}$.

\section{Materials and Methods}

The experiment was conducted in a greenhouse at the National Center for Cotton Research (Embrapa Algodão) in Campina Grande-PB, located at an altitude of $551 \mathrm{~m}$ with geographic coordinates 7 13 '50"'S latitude, 3552'52'W longitude, Awi and climate (tropical wet) according to the Köppen classification, with an average annual temperature of $28.6{ }^{\circ} \mathrm{C}$ and a minimum of $19.5{ }^{\circ} \mathrm{C}$. Samples of four soils with different chemical, physical and mineralogical characteristics, collected at depths of 0-30 cm, corresponding to topsoil, were brought to the experiment site (Embrapa Algodão, Campina Grande-PB). Soil samples Orthic Chromic Luvisol (TCo); Eutrophic Haplic Cambisol (CXbe); Fluvic (RY); Typical Eutrophic Cambisol (CXve), air dried and pressed through a $2 \mathrm{~mm}$ mesh sieve for physical and chemical characterization (Table 1) as Embrapa (1997). The experiment consisted of four soils and five doses of $\mathrm{P}_{2} \mathrm{O}_{5}$ in a completely randomized design with four replicates. Each experimental unit consisted of a vase containing $20 \mathrm{dm}^{-3}$ of soil and a castor bean plant, cultivar BRS Energia.

The soil samples were ground and air-dried, and then passed through a sieve with a mesh of $4 \mathrm{~mm}$. Then the pots were conditioned and weighed to a constant weight of $23 \mathrm{~kg}$. Each soil type received five doses of $\mathrm{P}, 0.0,43.75,87.5,175$, and $350 \mathrm{mg}$ $\mathrm{dm}^{-3}$ for TCo and CXve, 0.0, 60, 120, 240 and 480 
$\mathrm{mg} \mathrm{dm}{ }^{-3}$ for CXbe and 0.0, 51.25, 102.5, 205 and $410 \mathrm{mg} \mathrm{dm}^{-3}$ for RY, using the triple superphosphate as a source of $\mathrm{P}_{2} \mathrm{O}_{5}$. The doses of $\mathrm{P}_{2} \mathrm{O}_{5}$ for each soil type were determined according to the remaining $\mathrm{P}$ (Rem-P) following the methodology of Alvarez et al. (2000). To supply other macro and micronutrients was applied a weekly nutrient solution (HOAGLAND; ARNOND, 1950) was applied with all essential nutrients except $\mathrm{P}$.

Table 1. Chemical and physical characteristics of the four soils.

\begin{tabular}{|c|c|c|c|c|}
\hline \multirow{2}{*}{ Characteristics } & \multicolumn{4}{|c|}{ Sois } \\
\hline & TCo & CXbe & RY & CXve \\
\hline $\mathbf{p H ~} \mathrm{H}_{2} \mathrm{O}(1: 2,5)$ & 6,8 & 6,6 & 6,8 & 6,5 \\
\hline $\mathbf{C a}^{+2}\left(\mathrm{mmol} \mathrm{dm}^{-3}\right)$ & 76,9 & 182,1 & 145,3 & 31,0 \\
\hline $\mathbf{M g}^{+2}\left(\mathrm{mmol}_{\mathrm{c}} \mathrm{dm}^{-3}\right)$ & 29,5 & 39,3 & 63,5 & 20,5 \\
\hline $\mathbf{N a}^{+}\left(\mathrm{mmol} \mathrm{dm}^{-3}\right)$ & 1,1 & 0,7 & 1,1 & 0,5 \\
\hline $\mathbf{K}^{+}\left(\mathrm{mmol}_{\mathrm{c}} \mathrm{dm}^{-3}\right)$ & 5,1 & 13,5 & 4,8 & 6,2 \\
\hline $\mathbf{S B}\left(\mathrm{mmol}_{\mathrm{c}} \mathrm{dm}^{-3}\right)$ & 112,6 & 235,6 & 214,7 & 58,2 \\
\hline $\mathbf{H}+\mathbf{A l}\left(\mathrm{mmol}_{\mathrm{c}} \mathrm{dm}^{-3}\right)$ & 12,4 & 38,0 & 28,1 & 12,4 \\
\hline $\mathbf{T}\left(\mathrm{mmol}_{\mathrm{c}} \mathrm{dm}^{-3}\right)$ & 125,0 & 273,6 & 242,8 & 70,6 \\
\hline$V(\%)$ & 90 & 86 & 88 & 82 \\
\hline $\left.\mathbf{A l}^{+3} \mathrm{mmol}_{\mathrm{c}} \mathrm{dm}^{-3}\right)$ & 0,5 & 0,5 & 0,5 & 0,5 \\
\hline $\mathbf{P} \mathrm{mg} \mathrm{dm}^{-3}$ (Melich-1) & 296,2 & 286,8 & 8,90 & 22,5 \\
\hline M.O $\left(\mathrm{g} \mathrm{kg}^{-1}\right)$ & 11,2 & 28,8 & 20,9 & 10,2 \\
\hline Rem-P $\left(\mathrm{mg} \mathrm{L}^{-1}\right)$ & 43,73 & 16,28 & 27,34 & 41,34 \\
\hline MPAC $\left(\mathrm{mg} \mathrm{g}^{-1}\right)$ & 0,279 & 0,297 & 0,395 & 0,293 \\
\hline Sand $\left(\mathrm{g} \mathrm{kg}^{-1}\right)$ & 726,4 & 716,8 & 450,1 & 726,6 \\
\hline Silt $\left(\mathrm{g} \mathrm{kg}^{-1}\right)$ & 138,0 & 28,3 & 234,8 & 148,0 \\
\hline Clay $\left(\mathrm{g} \mathrm{kg}^{-1}\right)$ & 135,6 & 254,9 & 330,0 & 125,4 \\
\hline
\end{tabular}

TCo: Chromic Orthic Luvisol; CXbe: Eutrophic Haplic Cambisol; RY: Fluvic; CXve: Typical Eutrophic Cambisol. SB: sum of bases; T: cation exchange capacity; V(\%): base saturation; Rem-P: remaining phosphorus; MPAC: maximum adsorption capacity of phosphorus.

Source: Elaboration of the authors.

After application of the different $\mathrm{P}$ doses, the soil was incubated for a period of 15 days, adding distilled water in an amount corresponding to $50 \%$ of the field capacity of each soil. After the incubation period, the soil was maintained at $70 \%$ of field capacity, the water requirement being determined by the method of weighing the pot (PEREIRA et al, 2005), and then three seeds of castor BRS Energia were sown per pot. Ten days after germination thinning was done, leaving one plant per pot. At the end of the experiment plant height, stem diameter, leaf area, and dry mass were measured. Height was measured with a millimeter ruler, measuring from the neck to the apex of the plant. The diameter was measured with the aid of a digital caliper. The leaf area was determined by measuring the length and width of the sheets. The shoot dry weight was determined by separating the plant stem and leaves. Then the plant material was washed, first in running water and then with distilled water. The material was dried in an oven with forced air circulation at $65^{\circ} \mathrm{C}$ until a constant weight was achieved and then weighed on an analytical balance accurate to $0.01 \mathrm{~g}$ to obtain the dry weight. The shoot dry mass was ground in a Wiley type mill, digested by sulfuric acid digestion (TEDESCO, 1995) and the $\mathrm{P}$ in the extracts assayed by colorimetry (BRAGA; DEFELIPO, 1974). 
Dry matter production corresponding to $90 \%$ of the "maximum physical efficiency" (MEF) ( $\mathrm{P}$ dose responsible for maximum plant dry matter production) was considered as "maximum economic efficiency" (MEE). Regression equations were adjusted relating dry weight and the amount of $\mathrm{P}$ accumulated in the shoots as variables of the $\mathrm{P}$ doses applied. The critical level of $\mathrm{P}$ in shoots was obtained by substituting the value of the $\mathrm{P}$ dose to $90 \%$ of the maximum in the regression equation between $\mathrm{P}$ content in dry matter and $\mathrm{P}$ dose applied.

\section{Results and Discussion}

The data relating to plant height growth dependence on the $\mathrm{P}$ doses for the four soils (TCo CXbe, RY and CXve) are shown in Figure 1. In general, it was observed that the application of increasing doses of $\mathrm{P}$ increased plant height with a quadratic polynomial fit for both soils, reducing the time for a given level of $\mathrm{P}$ applied to the soil. Severino et al. (2006) working with this same cultivar in field conditions, also found crop response to phosphorus fertilization for growth traits, such as height and stem diameter.

Figure 1. Growth in plant height (cm) of castor bean in Chromic Orthic Luvisol (A), Eutrophic Haplic Cambisol (B), Fluvic (C) and Typical Eutrophic Cambisol (D). Campina Grande, 2011.
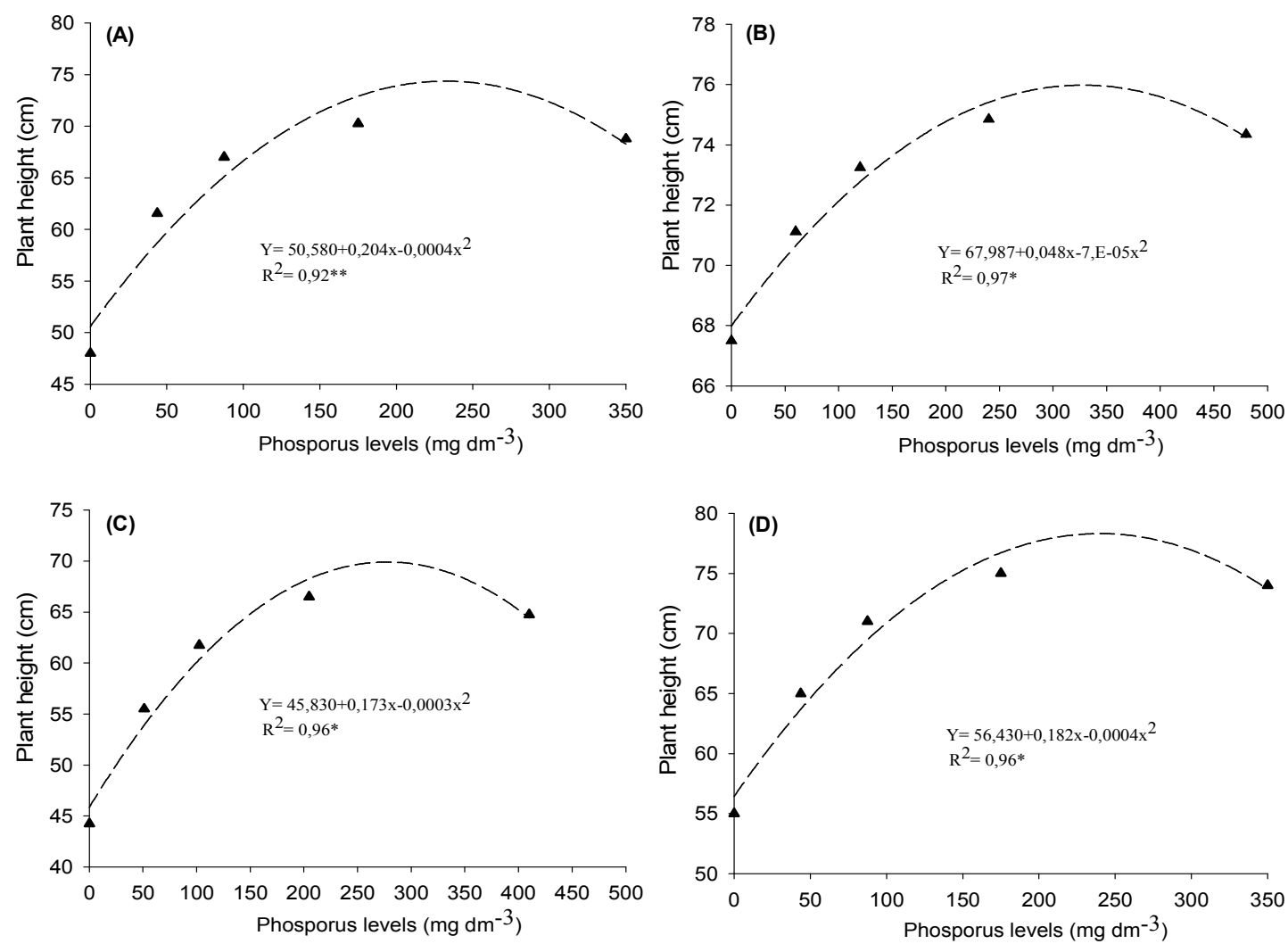

Source: Elaboration of the authors.

With TCo, an increase in height growth was found with $\mathrm{P}$ dose, with a dose of $229.6 \mathrm{mg} \mathrm{dm}^{-3}$ responsible for the maximum height $(74.3 \mathrm{~cm})$, and with a decrease in height with the application of higher doses (Figure 1A). With CXbe (Figure 1B), the height increased up to a dose of 331.8 $\mathrm{mg} \mathrm{dm}{ }^{-3}$, which was responsible for a height of $75.98 \mathrm{~cm}$; however, the application of higher doses 
caused reductions in plant height. Despite the small difference in height in the soil TCo and CXbe, there was a considerable difference in the amount of $\mathrm{P}$ applied to these soils to obtain similar heights, which probably resulted from the greater fixing capacity for $\mathrm{P}$ in CXbe.

In the case of RY (Figure 1C), we found the lowest plant height $(69.9 \mathrm{~cm})$ among the soils, this time related to a dose of $277 \mathrm{mg} \mathrm{dm}^{-3}$ applied $\mathrm{P}$. This result is probably due to its high clay content (Table 1) and consequently its high $\mathrm{P}$ fixing capacity competing strongly with the plant for $\mathrm{P}$, so it is necessary to apply higher doses of $\mathrm{P}$ in order to raise the level of $\mathrm{P}$ in soil solution. However, the greatest plant height $(78.3 \mathrm{~cm})$ was obtained at a dose of 223.2 mg dm ${ }^{-3}$ with CXve, demonstrating its low P fixing capacity, making a greater amount of $\mathrm{P}$ available to the plants (Figure 1D). Almeida Júnior et al. (2009), evaluating the response of BRS Nordestina to different doses of phosphorus, also concluded that the castor bean responds to fertilization, displaying increases in growth parameters with increasing levels of $\mathrm{P}$ applied to the soil.

Significant effects of $\mathrm{P}$ dose on the variable stem diameter, adjusted to the quadratic polynomial model, verified that the variable decreased when the highest doses were used in both soils. With TCo (Figure 2A), we observed an increase in stem diameter, with the maximum diameter $(17.12 \mathrm{~mm})$ achieved with a dose of $243.3 \mathrm{mg} \mathrm{dm}^{-3}$, and with a decrease in stem diameter with further application of a higher dose. Possibly the effect of phosphorus in improving the stem diameters of castor bean plants is due to the fact that this nutrient plays a structural function, forming a part of organic compounds vital to the growth of plants, especially ATP, vital as an energy transfer agent for every organic synthesis event in a plant (PRADO, 2008). However, excessive P may compromise the growth and production of plants due to the reduction of $\mathrm{CO}_{2}$ and starch synthesis, besides causing an unbalanced nutrition, particularly with $\mathrm{Cu}, \mathrm{Fe}, \mathrm{Zn}$ and $\mathrm{Mn}$, as noted Abreu, Lopes and Santos (2007) working with $\mathrm{P}$ doses exceeding $66.49 \mathrm{~kg}^{-1}$ for the castor bean.

In CXbe (Figure 2B), we observed behavior similar to TCo, with maximum stem diameter $(16.90 \mathrm{~mm})$ observed with a dose of $318.9 \mathrm{mg} \mathrm{dm}^{-3}$. According Novais and Smyth (1999), this behavior can be explained based on the clay content and higher FCP that soil, making it necessary, higher doses of $\mathrm{P}$ relative to the values observed for stem diameter in TCo, which has lower FCP, agreeing with the observations made by Bonfim et al. (2004), working with Brachiaria brizhanta, verified influence of FCP on the critical levels of P in plants, observing lower values in soils with higher FCP and high clay content. As for RY, there was a similar behavior, with an increase in stem diameter (16.3 $\mathrm{mm}$ ) for the dose of $270.6 \mathrm{mg} \mathrm{dm}^{-3}$, with a decline in this variable at still higher doses (Figure 2C). This result is consistent with the results observed for plant height in the same soil, which may be related to characteristics of this soil such as high clay content, giving the soil a high FCP. Almeida Júnior et al. (2009) and Martins et al. (2010) also found quadratic adjustment for height and stem diameter of castor bean plants subjected to increasing doses of $P$.

The largest diameter stem $(17.58 \mathrm{~mm})$ was observed in CXve with application of $229.6 \mathrm{mg}$ $\mathrm{dm}^{-3}$ of $\mathrm{P}$, followed by variable decreases when higher doses of $\mathrm{P}$ were used (Figure 2D). These results are similar to those observed with TCo and can thus be explained by the low clay content and hence lower FCP, which results in less competition with the soil by the plant for available P. Mesquita et al. (2012) working with P levels in castor bean found no significant effect of this element on the stem diameter of the plants, however, Almeida Júnior et al. (2009) observed effects of P rates (0, 3, $6,9,12$ and $\left.15 \mathrm{~g} \mathrm{plant}^{-1}\right)$ in the initial development of castor bean plants. 
Figure 2. Growth in plant stem diameters $(\mathrm{mm})$ of castor bean in Chromic Orthic Luvisol (A), Eutrophic Haplic Cambisol (B), Fluvic (C) and Typical Eutrophic Cambisol (D). Campina Grande, 2011.
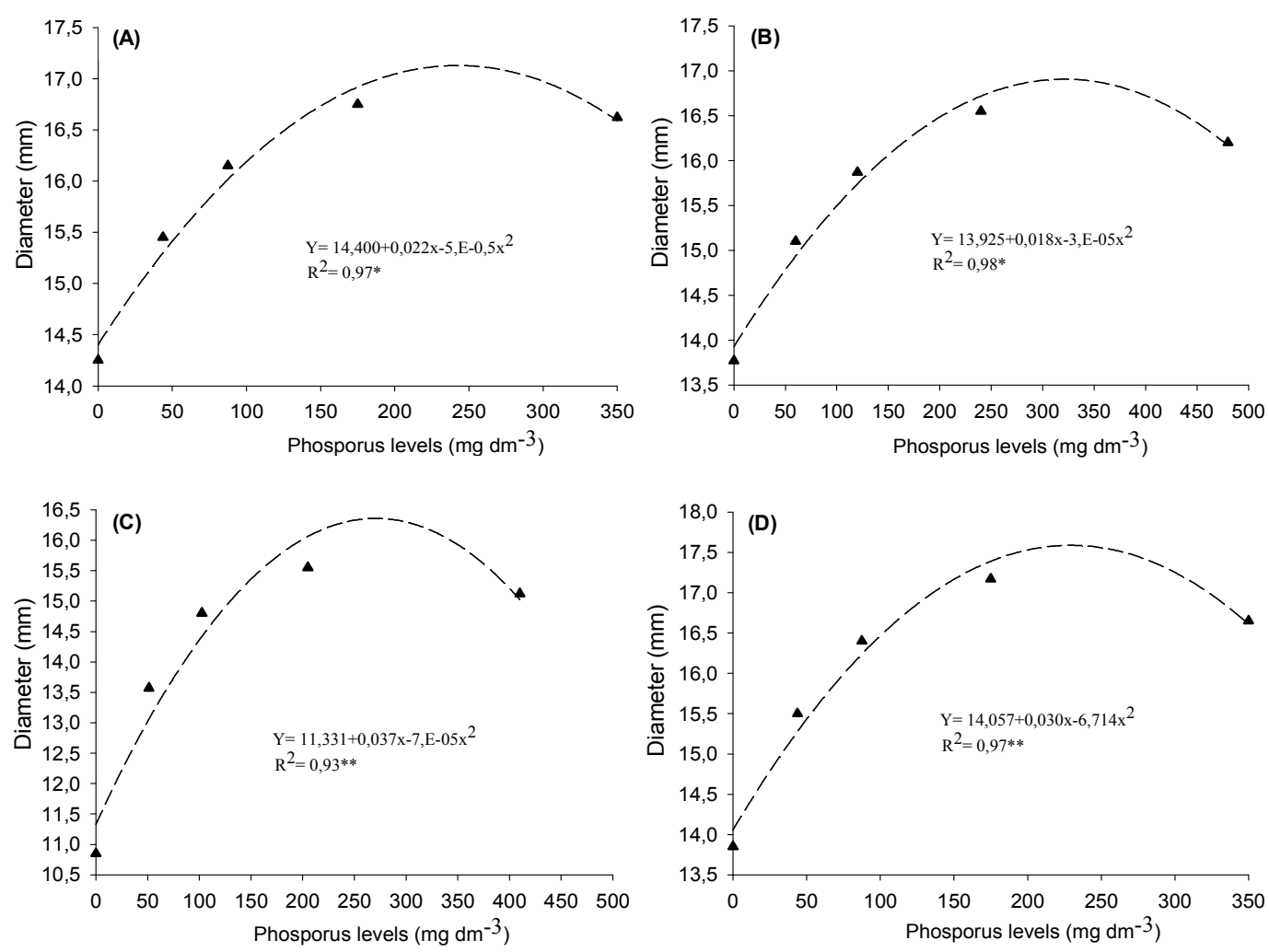

Source: Elaboration of the authors.

For leaf area the behavior was found to be similar to that seen with other variables (Figure 3A, $\mathrm{B}, \mathrm{C}$ and D). For soil TCo, there was an increase in leaf area up to a dose of $228.3 \mathrm{mg} \mathrm{dm}^{-3}$; however, application of higher doses promoted decreases in the leaf area of the castor bean (Fig. 3A). In CXbe soil (Figure 3B), there was an increase in leaf area up to a dose of $309.3 \mathrm{mg} \mathrm{dm}^{-3}$. These results are probably related to the chemical characteristics of the soil, such as its clay content $\left(254.9 \mathrm{~g} \mathrm{~kg}^{-1}\right)$, due to the high fixing capacity of this soil for $\mathrm{P}$ and thus requiring a high dose of $\mathrm{P}$ to increase the area leaf.

The leaf area of the RY soil (Figure 3C) showed similar results to that observed with CXbe; however, the castor leaf area in RY obtained was lower (4724.8 $\mathrm{cm}^{2}$ ) with a dose of $280.2 \mathrm{mg} \mathrm{dm}{ }^{-3}$. These results confirm those found by Almeida Júnior et al. (2009), who evaluated escalating doses of phosphorus and found that the leaf area of BRS Nordestina showed a quadratic response to increasing doses of $\mathrm{P}$, highlighting the importance of nutrition in the early stage of culture. Jeschke et al., (1996) studying the effect of $\mathrm{P}$ on leaf development in castor beans, noted that leaf area was affected by a low supply of phosphorus because plants grown in solution with an adequate supply had $23 \%$ greater leaf area than those maintained at a low concentration of $\mathrm{P}$.

For the CXve soil, increasing the dose of $\mathrm{P}_{2} \mathrm{O}_{5}$ applied increased the leaf area of the castor bean (Figure 3D) up to $240.6 \mathrm{mg} \mathrm{dm}^{-3}$, this dose being responsible for most of the increase in leaf area $\left(4621.01 \mathrm{~cm}^{2}\right)$. It was possible to observe similar behavior in the results for leaf area in soils TCo and CXve, considering the $\mathrm{P}$ doses responsible for maximum leaf area. This similarity is directly related to the characteristics of these soils; those which showed the lowest clay content also exhibited the lowest $P$ fixing capacity and a greater amount of $P$ available to plants. Machado et al. (2011) working with $\mathrm{P}$ availability in soils with different textures, 
observed an increased availability of $\mathrm{P}$ in sandy soil, noting the need to manage the phosphorus, considering the clay content and soil FCP. These results corroborate Falcão and Silva (2004), who found lower P adsorption in sandy soils than in clay more.

Figure 3. Growth in plant leaf area (cm2) of castor bean in Chromic Orthic Luvisol (A), Eutrophic Haplic Cambisol (B), Fluvic (C) and Typical Eutrophic Cambisol (D). Campina Grande, 2011.
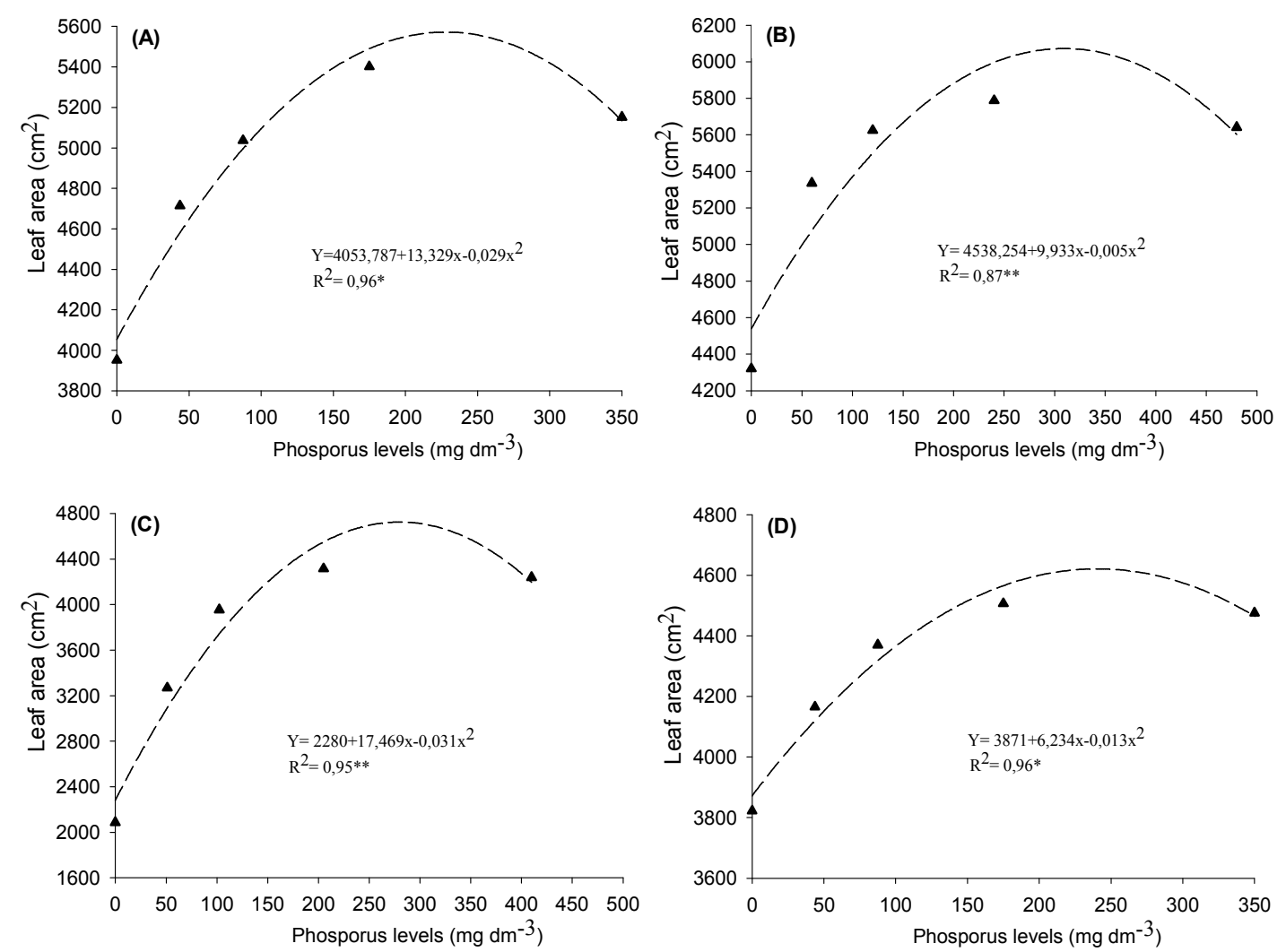

Source: Elaboration of the authors.

In general, in the results of this study it was found that castor plants greatly increase their growth with phosphate. According to Pacheco et al. (2008), the yield of castor bean is more influenced by phosphorus, disagreeing with the results found by Severino et al. (2006), who found greater response to nitrogen, followed by phosphorus and potassium. Silva et al. (2012) observed a significant increase in productivity of castor bean yield of $1,116 \mathrm{~kg}$ $\mathrm{ha}^{-1}$ at a dose of $134.10 \mathrm{~kg} \mathrm{ha}^{-1}$ of $\mathrm{P}_{2} \mathrm{O}_{5}$. Increased productivity in the castor bean was also observed by Oliveira et al. (2010) in a study conducted with increasing doses of $\mathrm{P}_{2} \mathrm{O}_{5}$. Soils with higher clay contents adsorb greater quantities of $\mathrm{P}$, which makes it necessary to fertilize with higher doses of phosphate fertilizer. Moreover, in soils with low levels of clay, a lower amount of phosphate fertilizer is needed to achieve good growth of the castor plant. Thus, recommendations for phosphorus fertilization should be based on the levels of phosphorus in the soil and its clay content. According to Costa et al. (2006), due to the high FCP of clayey soils, only achieved a small change in the amount of $P$ in the soil solution, applying very high doses of $\mathrm{P}$, which are no longer economic.

The curves for dry matter production in castor 
bean shoots in response to phosphorus levels applied to TCo, CXbe, RY and CXve are presented in Figure 4. The production of dry mass in the shoots according to applied Prates was adjusted to quadratic models with high coefficients of determination and decreasing increments (Mitscherlich) between doses of $\mathrm{P}$ and shoot dry matter production. Similar behavior was observed by Almeida Júnior et al. (2009) in a study conducted with increasing doses of phosphorus on the growth of castor bean, verifying quadratic fit to the accumulation of total dry matter increments up to a dose of $8.8 \mathrm{~g}_{\text {plant }}{ }^{-1}$ (44.8 g), however, higher doses of $\mathrm{P}$ decreased the accumulation of total dry matter of the castor.

The shoot dry matter production ranged from 34.65 to $33.55 \mathrm{~g} \mathrm{pot}^{-1}$ in soils with lower clay contents and higher Prem contents (CXve and TCo) (Figure 4A and 4D), respectively. Thus, we can see that the highest shoot dry matter yield was obtained in soils with poor fixing capacity for P. The soil clay content presented TCo and Prem of 135 and 250 respectively and maximum economic efficiency (34.65 $\mathrm{g} \mathrm{pot}^{-1}$ ) was Achieved with an Estimated dose of $87.94 \mathrm{mg} \mathrm{dm}^{-3}$. Similar behavior was observed for CXve, which had a clay content of $125.4 \mathrm{~g} \mathrm{~kg}^{-1}$. In this soil, maximum economic efficiency (33.55 $\mathrm{g}$ pot $^{-1}$ ) was obtained with an estimated $\mathrm{P}$ dose of $104.33 \mathrm{mg} \mathrm{dm}^{-3}$.

In soils with higher clay content (CXbe and RY) shoot dry weights ranged from 31.86 to $27.43 \mathrm{~g}$ pot $^{-1}$ (Figure 4B and 4C), respectively. These soils, which have a higher phosphorus adsorption fixing also required the highest doses of P. For CXbe, with $254.9 \mathrm{~g} \mathrm{~kg}^{-1}$ clay, the maximum economic efficiency (31.86 $\mathrm{g} \mathrm{pot}^{-1}$ ) was related to an estimated dose of $132.18 \mathrm{mg} \mathrm{dm}^{-3}$ of P. For RY, with a clay content of $330 \mathrm{~g} \mathrm{~kg}^{-1}$, an estimated dose of $124.63 \mathrm{mg} \mathrm{dm}^{-3}$ $\mathrm{P}$ was needed to obtain $27.43 \mathrm{~g} \mathrm{pot}^{-1}$ of shoot dry matter production (Figure 4B and 4C).

Figure 4. Estimated $\mathrm{P}$ doses for $90 \%$ of the maximum shoot dry mass of castor bean in Chromic Orthic Luvisol (A), Eutrophic Haplic Cambisol (B), Fluvic (C) and Typical Eutrophic Cambisol (D). Campina Grande, 2011.
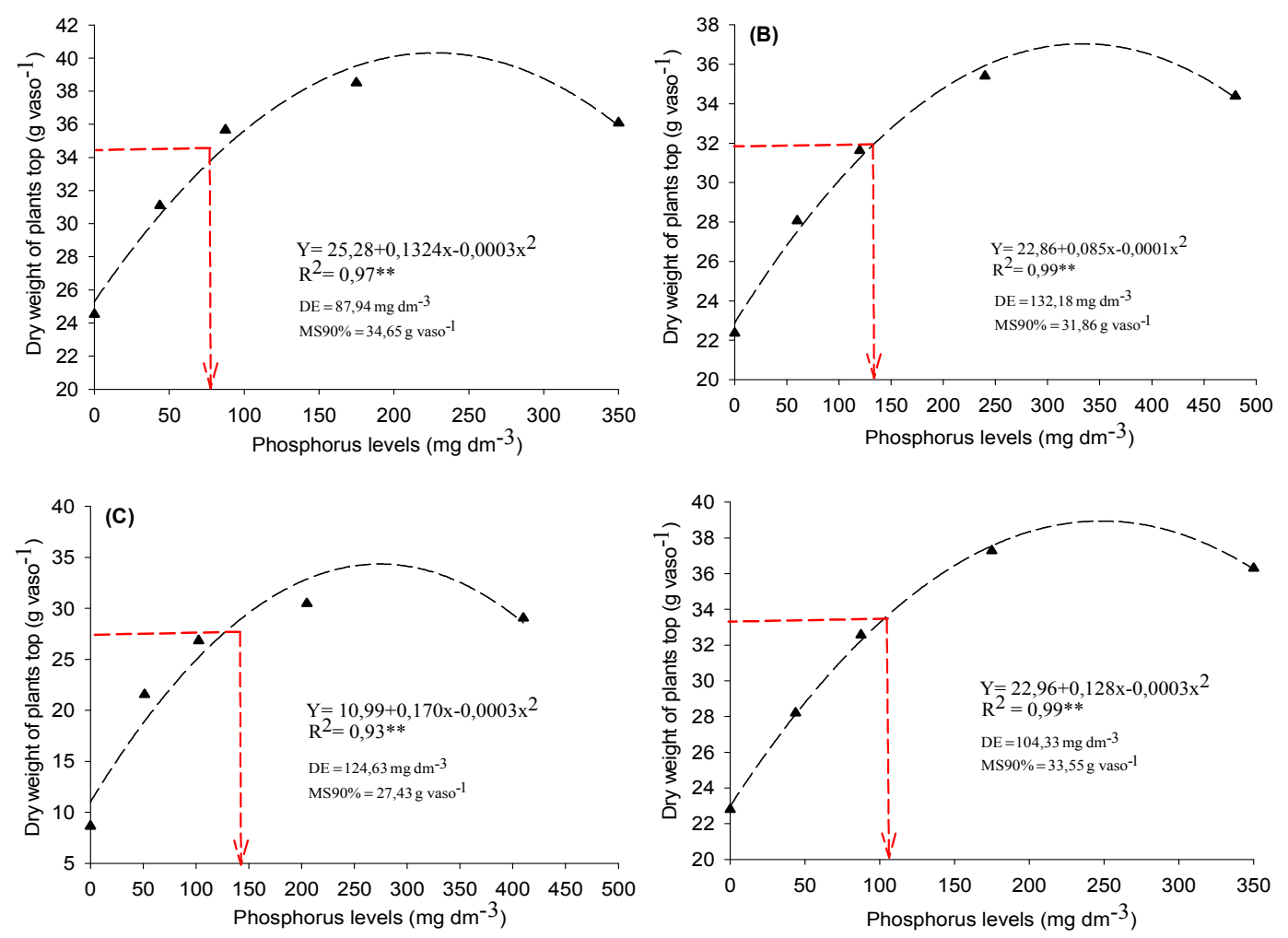

Source: Elaboration of the authors. 
These results demonstrate that a higher dose of $\mathrm{P}$ is needed in soils with a higher fixing capacity for $\mathrm{P}$ (CXbe and RY), for mass production of dry matter per unit $\mathrm{P}$, confirming the high fixing capacity of these soils for P. Based on the results, the importance of clay on $\mathrm{P}$ adsorption and availability to plants is evident. Novais and Smyth (1999) reported that in soils with high $\mathrm{P}$ adsorption capacities, as is the case with CXbe and RY (Figure 4B and 4C), the plant optimizes the low concentration of $\mathrm{P}$ in solution that is available, yielding more biomass per unit of absorbed $\mathrm{P}$ than in soils with low $\mathrm{P}$ fixing capacities.

Figure 5. Critical level of $\mathrm{P}$ for $90 \%$ of the maximum dry shoot mass of castor bean in Chromic Orthic Luvisol (A), Eutrophic Haplic Cambisol (B), Fluvic (C) and Typical Eutrophic Cambisol (D). Campina Grande, 2011.
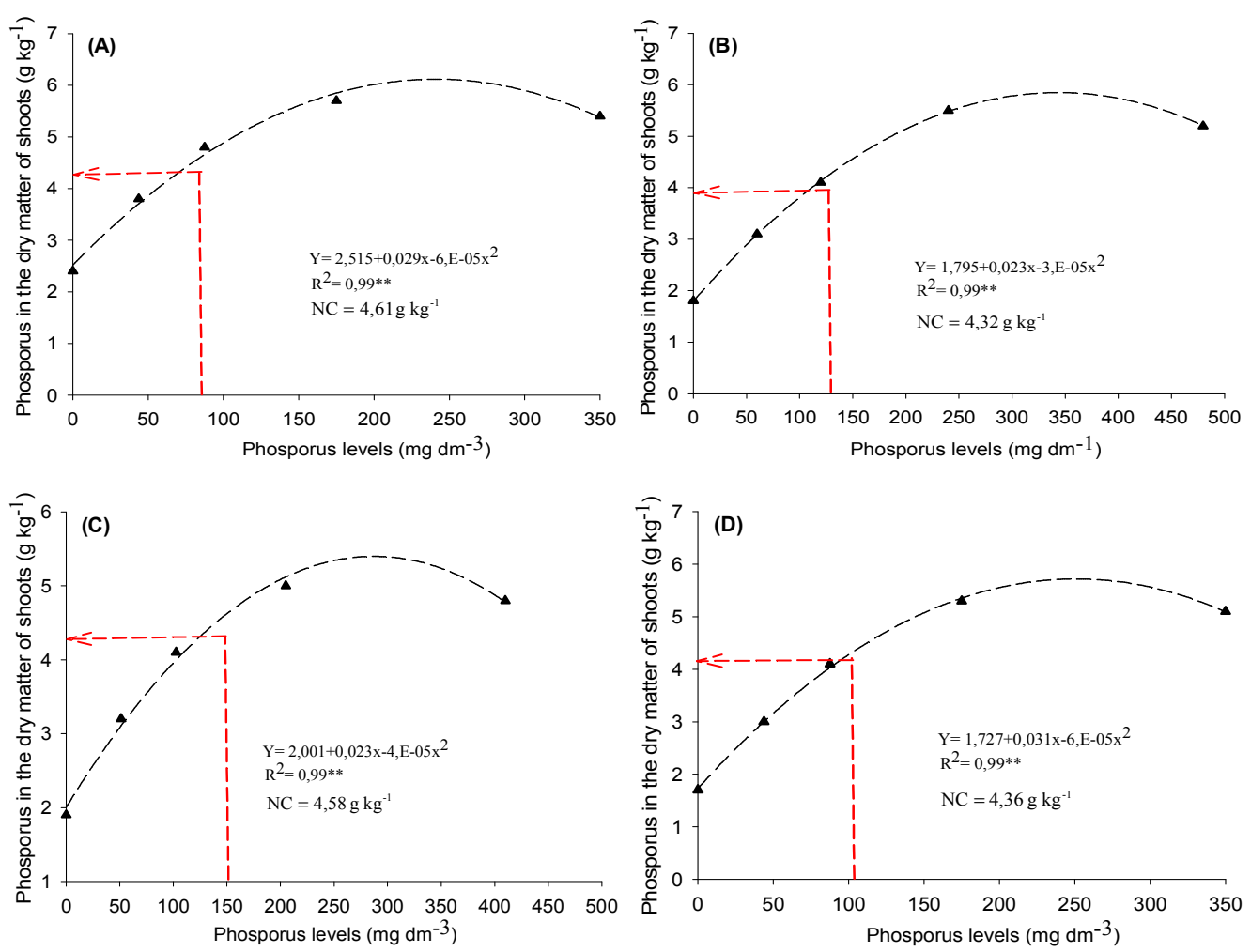

Source: Elaboration of the authors.

The phosphorus content in the shoot dry weight of the plants showed a quadratic fit to the $\mathrm{P}$ concentration in the soil (Figure 5A, B, C and D). According to the literature (NOVAIS; SMYTH, 1999), soils with greater fixing capacity of $P$, have lower levels of $\mathrm{P}$ in the plant, whereas in soil, the $\mathrm{P}$ critical level is higher for soils with low fixing capacity. In general, the critical levels of $\mathrm{P}$ in the shoots of the plants did not vary much among the soils. The critical level of $\mathrm{P}$ in shoots was highest
(4.61 $\mathrm{g} \mathrm{kg}^{-1}$ ) in TCo (Figure 5A). Muniz et al. (1985) found a wide range of variations between critical levels of P in shoots of soybean plants grown in soils with different capacities for phosphorus adsorption, with the lowest values observed in soils with higher $\mathrm{P}$ fixing capacity. The critical level of $\mathrm{P}$ in shoots of CXbe checked the soil was $4.32 \mathrm{~g} \mathrm{~kg}^{-1}$, the lowest value found for any of the soils (Figure 5B). This result is probably directly related to its high clay content $\left(254.9 \mathrm{~g} \mathrm{~kg}^{-1}\right)$, so that there is greater 
$\mathrm{P}$ adsorption, rendering it unavailable to plants. However, RY soil showed a high critical P content (4.58 $\mathrm{g} \mathrm{kg}^{-1}$ ) even with a high $\mathrm{P}$ fixing capacity due to a high clay content $\left(330 \mathrm{~g} \mathrm{~kg}^{-1}\right)$, in disagreement with studies in the literature (NOVAIS; SMYTH, 1999; BEDIN et al., 2003) that demonstrate the greater the $\mathrm{P}$ fixing capacity of the soil, the low the critical level of $\mathrm{P}$ in plants (Figure 5C). Probably, besides the clay content in this soil, its mineralogy also interfered with the availability of this element, and therefore with critical levels of $\mathrm{P}$ in the plants.

In an experiment with samples of four lowland soils, Fernandes et al. (2000) determined that critical levels of $\mathrm{P}$ for dry matter production by bean shoots were inversely related to the P fixing capacity. In the case of CXve (Figure 5D) the critical level of $\mathrm{P}$ was found to be $4.36 \mathrm{~g} \mathrm{~kg}^{-1}$, a result that disagrees with studies in the literature (BONFIM et al., 2004; FARIAS et al., 2009), taking into account the low fixing capacity of this soil.

\section{Conclusions}

The variables plant height, stem diameter and leaf area were significantly influenced by P dose, with the highest average observed in soil CXve with $125.4 \mathrm{~g} \mathrm{~kg}^{-1}$ clay;

In TCo, with $135.6 \mathrm{~g} \mathrm{~kg}^{-1}$ clay, the greatest shoot dry matter production was obtained with a dose of $87.94 \mathrm{mg} \mathrm{dm}^{-3} \mathrm{P}$, while in soil RY with $330 \mathrm{~g} \mathrm{~kg}^{-1}$ clay, the highest dry matter yield was obtained with a dose of $124.63 \mathrm{mg} \mathrm{dm}^{-3} \mathrm{P}$;

The critical level of $\mathrm{P}$ for castor bean shoot dry mass was the highest (4.61 $\left.\mathrm{g} \mathrm{kg}^{-1}\right)$ in TCo, which a has the highest clay content.

\section{References}

ABREU, C. A.; LOPES, A. S.; SANTOS, G. Micronutrientes. In: NOVAIS, R. F.; ALVAREZ, V. V. H.; BARROS, N. F.; FONTES, R. L. F.; CANTARUTTI, R. B.; NEVES, J. C. L. (Ed.). Fertilidade do solo. Viçosa: SBCS/UFV, 2007. p. 645-736.
ALLEN, B. L.; HAJEK, B. F. Mineral occurrence in soil environments. In: DIXON, J. B.; WEED, S. B. Minerals in soil environments. 2. ed. Madison: Soil Science Society of America, 1989. p. 199-278.

ALMEIDA JUNIOR, A. B.; OLIVEIRA, F. A.; MEDEIROS, J. F.; OLIVEIRA, M. K. T. de.; LINHARES, P. C. F. Efeito de doses de fósforo no desenvolvimento inicial da mamoneira. Revista Caatinga, Mossoró, v. 22, n. 1, p. 217-221, 2009.

ALVAREZ, V. V. H.; NOVAIS, R. F.; DIAS, L. E.; OLIVEIRA, J. A. Determinação e uso do fósforo remanescente. Boletim Informativo da Sociedade Brasileira de Ciência do Solo, Viçosa, MG, n. 25, p. 2732, 2000.

BEDIN, I.; FURTINI NETO, A. E.; RESENDE, A. V.; FAQUIN, A.; TOKURA, A. M.; SANTOS, J. Z. L. Fertilizantes fosfatados e produção da soja em solos com diferentes capacidades tampão de fosfato. Revista Brasileira de Ciência do Solo, Viçosa, MG, v. 27, n. 4, p. 639-646, 2003.

BELTRÃO, N. E. de. M.; AZEVEDO, M. P. de. Fitologia. In: AZEVEDO, D. M. P.; BELTRÃO, N. E. de M. (Ed.). O agronegócio da mamona no Brasil. 2. ed. rev. e ampl. Campina Grande: EMBRAPA Algodão, 2007. p. 117137.

BONFIM, E. M. S.; FREIRE, F. J.; SANTOS, M. V. F.; SILVA, T. J. A.; FREIRE, M. B. G. S. Níveis críticos de fósforo para brachiaria brizantha e suas relações com características físicas e químicas em solos de Pernambuco. Revista Brasileira de Ciência do Solo, Viçosa, MG, v. 28, n. 2, p. 281-288, 2004.

BRAGA, J. M.; DEFELIPO, B. V. Determinação espectrofotométrica de fósforo em extratos de solo e material vegetal. Revista Ceres, Viçosa, MG, v. 21, n. 1, p. 73-85, 1974.

COSTA, F. X.; BELTRAO, N. E. de M.; MELO FILHO, J. S.; SILVA, D. P.; DANTAS, G. F.; SILVA, F. E. de A. Avaliação da fisiologia e bioquímica da mamoneira em função da aplicação de composto orgânico de lixo e torta de mamona como fertilizantes. Engenharia Ambiental, Espírito Santo do Pinhal, v. 8, n. 1, p. 101-109, 2011.

COSTA, J. P. V.; BARROS, N. F.; ALBUQUERQUE, A. W.; MOURA FILHO, G.; SANTOS, J. R. Fluxo difusivo de fósforo em função de doses e da umidade do solo. Revista Brasileira de Engenharia Agrícola e Ambiental, Campina Grande, v. 10, n. 4, p. 828-835, 2006. 
EMPRESA BRASILEIRA DE PESQUISA AGROPECUÁRIA - EMBRAPA. Centro Nacional de Pesquisa de Solos. Manual de métodos de analise de solo. 2. ed. Rio de Janeiro: Rev. Atual, 1997. 212 p. (Documento, 1).

FALCÃO, N. P. S.; SILVA, J. R. A. Características de adsorção de fósforo em alguns solos da Amazônia Central. Acta Amazônica, Manaus, v. 34, n. 3, p. 337342, 2004.

FARIAS, D. R.; OLIVEIRA, F. H. T.; SANTOS, D.; ARRUDA, J. A.; HOFFMANN, R. B.; NOVAIS, R. F. Fósforo em solos representativos do estado da Paraíba. II- Disponibilidade de fósforo para plantas de milho. Revista Brasileira de Ciência do Solo, Viçosa, MG, v. 33, n. 3, p. 633-646, 2009.

FERNANDES, L. A.; FAQUIN, V.; FURTINI NETO, A. E.; CURI, N. Frações de fósforo e atividade da fosfatase ácida em plantas de feijoeiro cultivadas em solos de várzea. Revista Brasileira de Ciência do Solo, Viçosa, MG, v. 24, n. 3, p. 561-571, 2000.

GATIBONI, C. L. Disponibilidade de formas de fósforo do solo às plantas. 2003. Tese (Doutorado em Agronomia/ Biodinâmica dos Solos) - Universidade Federal de Santa Maria, Santa Maria.

HOAGLAND, D. R.; ARNON, D. L. The water culture methods for growin plants without soil. Berkeley: Agriculture Experiment Station, 1950. 32 p. (Buletin, 347).

MACHADO, V. J.; SOUZA, C. H. E.; ANDRADE, B. B. de; LANA, R. M. Q.; KORNDORFER, G. H. Curvas de disponibilidade de fósforo em solos com diferentes texturas após aplicação de doses crescentes de fosfato monoamônico. Bioscience Journal, Uberlândia, v. 27, n. 1, p. 70-76, 2011.

MARTINS, L. D.; TOMAZ, M. A.; AMARAL, J. F. T.; LVIOLA, B. G.; BORCARTE, M. Desenvolvimento inicial de mamona e pinhão manso em solo submetido a diferentes corretivos e doses de fósforo. Revista Verde de Agroecologia e Desenvolvimento Sustentável, Mossoró, v. 5, n. 1, p. 143-150, 2010.

MESQUITA, E. F.; CHAVES, L. H. G.; GUERRA, H. O. C.; LACERDA, R. D. Crescimento e produção de duas cultivares de mamoneira sob fertilização NPK. Revista Caatinga, Mossoró, v. 25, n. 2, p. 35-43, 2012.
MUNIZ, A. S.; NOVAIS, R. F.; BARROS, N. F.; NEVES, J. C. L. Nível critico de fósforo na parte aérea da soja como variável do fator capacidade de fósforo. Revista Brasileira de Ciência do Solo, Campinas, v. 9, n. 3, p. 237-244, 1985.

NOVAIS, R. F.; SMITH, T. J. Fósforo em solo e planta em condições tropicais. Viçosa: Universidade Federal de Viçosa, 1999. 399 p.

OLIVEIRA, J. P. M.; SCIVITTARO, W. B.; CASTILHOS, R. M. V.; OLIVEIRA FILHO, L. C. I. Adubação fosfatada para cultivares de mamoneira no Rio Grande do Sul. Revista Ciência Rural, Santa Maria, v. 40, n. 8, p. 1835-1839, 2010.

PACHECO, D. D.; GONÇALVES, N. P.; SATURNINO, H. M.; ANTUNES, P. D. Produção e disponibilidade de nutrientes para mamoneira (Ricinus communis) adubada com NPK. Revista de Biologia e Ciências da Terra, Campina Grande, v. 8, n. 1, p. 153-160, 2008.

PEREIRA, J. R. D.; CARVALHO, J. A.; MIGUEL, D. S.; SANTANA, M. J. Consumo de água pela cultura do crisântemo cultivada em ambiente protegido. Engenharia Agrícola, Jaboticabal, v. 25, n. 3, p. 651-659, 2005.

PRADO, R. M. Manual de nutrição de plantas forrageiras. Jaboticabal: FUNEP, v. 1, 2008. 500 p.

ROLIM NETO, F. C.; SCHAEFER, C. E. G. R, COSTA, L. M.; CORREA, M. M.; FERNANDES FILHO, E. I.; IBRAIMO, M. M. Adsorção de fósforo, superfície específica e atributos mineralógicos em solos desenvolvidos de rochas vulcânicas do Alto Paranaíba, Minas Gerais. Revista Brasileira de Ciência do Solo, Viçosa, MG, v. 28, n. 6, p. 953-964, 2004.

SEVERINO, L. S.; FERREIRA, G. B.; MARAES, C. R. A.; GONDIM, T. M. S.; FREIRE, W. S. A.; CASTRO, D. A.; CARDOSO, G. D.; BELTRAO, N. E de M. Crescimento e produtividade da mamoneira adubada com macronutrientes e micronutrientes. Pesquisa Agropecuária Brasileira, Brasília, v. 41, n. 4, p. 563$568,2006$.

SILVA, D. F.; TRINDADE, R. C. P.; OLIVEIRA, M. W.; FERRO, H. de A.; CALHEIROS, A. S. Crescimento vegetativo e produtividade de mamoneira em função da variedade e da adubação fosfatada. Revista Caatinga, Mossoró, v. 25, n. 1, p. 160-167, 2012.

TEDESCO, M. J. Análise de solo, plantas e outros materiais. 2. ed. rev. ampl. Porto Alegre: Departamento de Solos, UFRGS, 1995. 174 p. (Boletim técnico, n. 5). 
